\title{
Indonesia Dalam Mewujudkan Sumber Daya Manusia Berkualitas di Era Revolusi Industri 4.0
}

Evelyn Mintarwan ; NRP 130118002 ; Ekonomi SDM ; KP-A

Fakultas Bisnis dan Ekonomika ; Universitas Surabaya ; November 2020

DOI 10.31219/OSF.IO/Q27PK

\begin{abstract}
Kondisi ketenagakerjaan di Indonesia saat ini sedang menghadapi berbagai tantangan. Khususnya tantangan menghadapi industri 4.0 yang menuntut SDM dapat memahami operasi pabrik cerdas, layanan cerdas, dan produk inovatif. Menanggapi hal itu, Indonesia sudah mulai menggarap Revolusi Industri 4.0 yang terlihat dari banyaknya pabrik-pabrik cerdas atau sering disebut dengan istilah Smart Factory. Dalam menghadapi era Revolusi Industri 4.0 yang masih tergolong baru ini, diperlukan persiapan khusus yang mendukung. Hal ini juga menjadi strategi Indonesia dalam menghadapi kompetisi SDM secara global. Paper ini akan ditulis dengan melakukan sitasi dari jurnal Indonesia's Efforts to Achieve Globally Competitive Human Resources yang ditulis oleh Ahmad Zafrullah Tayibnapis, Lucia Endang Wuryaningsih, dan Radita Gora.
\end{abstract}

\section{Introduction}

Industri nasional sangat membutuhkan perkembangan dan kemajuan teknologi, informasi dan komunikasi sehingga dapat digunakan disetiap rantai manufaktur. Melalui percepatan penerapan industri 4.0, Pemerintah telah berkomitmen untuk membangun industri manufaktur yang berdaya saing global dan industri tersebut dapat membawa Indonesia untuk memiliki kesempatan kompetitif di pasar global masa depan.

Pemerintah yang menerapkan revolusi industri 4.0 tidak akan bisa berjalan dengan baik bila tidak diseimbangi dengan sumber daya manusia yang berkualitas. Profesionalisme tiap bisnis juga akan diutamakan sehingga mampu melakukan inovasi berkelanjutan. Dalam melakukan inovasi berkelanjutan, kesiapan sumber daya manusia yang unggul dan berkualitas global itu penting agar Indonesia mampu bersaing di tingkat global. Saat ini kondisi ketenagakerjaan Indonesia memiliki mayoritas penduduk bekerja dengan pendidikan rendah yaitu SMP kebawah sebesar 56\%. (Machmudi, 2020). Hal itu menunjukan bahwa Indonesia sangat membutuhkan sumber daya manusia yang lebih baik agar mampu menghadapi revolusi industri 
4.0 yang mampu mengubah tatanan politik dan ekonomi. Apalagi dengan adanya teknologi akan membuat banyaknya pekerjaan yang hilang karena tergantikan. Oleh karena itu, sumber daya manusia perlu bersaing lebih ketat lagi dalam meningkatkan kualitas dan keunggulannya.

\section{Literature Review}

Berdasarkan Tayibnapis, Wuryaningsih, \& Gora (2018), perusahaan yang unggul merupakan perusahaan yang kompetitif dan mampu beradaptasi terhadap perubahan. Perubahan lingkungan akibat revolusi industri 4.0 membuat perusahaan harus dapat beradaptasi agar dapat bertahan dalam era global. Hal ini akan membuat banyak perusahaan meninggalkan strategi lama dan berubah ke strategi dan metode baru yang lebih efisien. Strategi dan metode baru tersebut akan berhubungan dengan sumber daya manusia yang layak agar sesuai dengan kebutuhan lingkungan kerja.

Penyesuaian strategi dan metode baru perusahaan pada sumber daya manusianya akan dilakukan melalui program pengembangan. Secara umum, pengembangan akan dilakukan melalui aktivitas pelatihan untuk meningkatkan pengetahuan dan skill pekerja. Pelatihan dapat diberikan baik untuk pekerja baru maupun yang sudah ada. Hal ini dikarenakan aktivitas pelatihan akan berfokus pada skills yang dibutuhkan saat ini. Pengembangan juga bisa dilakukan dalam lingkup manajemen yang memberikan dampak jangka panjang pada pekerja sehingga mampu menyelesaikan berbagai masalah dalam perusahaan. Seiring dengan pengembangan, pekerja akan memiliki prestasi menguntungkan yang harus terus-menerus ditingkatkan. Sedangkan prestasi yang tidak menguntungkan harus diperbaiki secepatnya.

Saat ini Indonesia masih memiliki sumber daya manusia yang berkualitas rendah. Peran pemerintah juga belum sepenuhnya memprioritaskan pengembangan sumber daya manusia. Selain itu, pendidikan di Indonesia juga memiliki kompetensi yang rendah sehingga tertinggal dibandingkan negara lainnya. Banyak orang masih takut dalam mengambil langkah yang berbeda sehingga lebih memilih menjadi pengikut dan menunggu orang lain melakukanya terlebih dahulu. Hal itu mengakibatkan pekerja mejadi tidak mampu berkembang dalam menghadapi era global. Oleh karena itu, pemimpin harus memberikan kesempatan pada pekerja untuk memiliki keunikan sehingga dapat berkembang dan selalu memotivasi serta memberikan aura positif.

Pemimpin dari perusahaan besar dan menengah di Indonesia melihat perkembangan kompetisi dan mencoba meningkatkan kualitas sumber daya manusianya agar mampu bersaing secara global. Seperti pada PT. Pertamina yang menerapkan Performance Management System 
dimana pekerjanya akan diberikan aspirasi dan kesempatan dalam mengungkapkan keinginan mereka untuk berubah bagian. Lalu PT. Telkom, Tbk yang memberikan pembangunan karakter, kompetensi, kolaborasi, dan kerja sama tim agar menciptakan banyak bakat dan penilaian pasar secara global. PT 3M Indonesia juga memiliki human resources development strategy yang disebut local leadership. Program dilakukan dengan tujuan agar sumber daya manusia memiliki kompetensi dan bakat seperti diberikan kesempatan untuk mengutarakan inovasi yang dimiliki pada perusahaan.

\section{Conclusion}

Revolusi Industri 4.0 memberikan dampak pada perubahan lingkungan kerja, sehingga penting untuk memperhatikan kualitas sumber daya manusia yang dimiliki guna menghadapi era global. Perusahaan harus mampu beradaptasi dan melakukan inovasi agar dapat menghadapi revolusi indsutri 4.0. Pemimpin akan memiliki keuntungan apabila sumber daya manusia yang dimiliki itu berbakat sehingga perubahan lingkungan akan mampu dihadapi dengan mudah.

Dalam pandangan pekerja memang uang itu penting, akan tetapi arti pekerjaan bagi mereka juga sama pentingnya. Oleh karena itu, perusahaan harus mampu memberikan tempat belajar bagi pekerja seperti memberikan fasilitas yang memadai. Seperti perusahaan besar dan menengah di Indonesia yang telah dibahas, mereka memberikan program serta strategi yang dapat meningkatkan kompetensi pekerja sehingga sumber daya manusia yang dimiliki berkualitas dalam menghadapi era global.

\section{References}

Machmudi, M. I. (2020, Juli 8). Menaker: Masalah Ketenagakerjaan Saat Ini Adalah Pendidikan. Retrieved from Media Indonesia: https://mediaindonesia.com/read/detail/326479-menakermasalah-ketenagakerjaan-saat-ini-adalah-pendidikan

Tayibnapis, A. Z., Wuryaningsih, L. E., \& Gora, R. (2018, August). Indonesia's Efforts to Achieve Globally Competitive Human Resources. International Journal of Humanities and Social Science Invention (IJHSSI), 7(08), 01-06. 